\title{
On the scientific concept of development and social development of Marxism inheritance
}

\author{
Yi ZHANG \\ Research Center of Marxism Theory \\ Xianyang Normal University \\ Xianyang, Shaanxi , 712000, China
}

\author{
Lizhang LUO \\ Research Center of Marxism Theory \\ Xianyang Normal University \\ Xianyang, Shaanxi , 712000, China
}

\begin{abstract}
Marxist theory of social development is a doctrine that is about the objective world, comprehensive and profound development. It combines the characteristics of the scientific development concept and practice requirements of the new era, and further reveals the core of our economic and social development, the basic requirements and fundamental approach as well as a vivid manifestation of the Marxist theory of social development. It is proposed that updated the concept of development, improved the theoretical system of socialism with Chinese characteristics. It is the major strategic thinking that the development of socialism with Chinese characteristics must adhere to and implement
\end{abstract}

Keywords- scientific concept of development; the Marxist theory of social development; social development

\section{INTRODUCTION}

Scientific concept of development deepening our party's understanding of the law of socialist modernization on the basis of inheriting the previous general understanding of the law of social development on the overall development of the law describes contemporary society, the coordinated development of the law and the law of sustainable development. It is not only to adhere to a comprehensive development of the society, but also to adhere to the coordinated development of society, so that all aspects of the development mutually reinforcing and positive interaction. At the same time, we must look to the future, and make the comprehensive development and sustainable development unified. So the new scientific concept of development is the development of Marxist philosophy dialectics.

\section{THE SCIENTIFIC CONCEPT OF DEVELOPMENT IS UNSWERVINGLY ADHERING TO THE ROAD OF SOCIALISM WITH CHINESE CHARACTERISTICS, IN LINE WITH THE OBJECTIVE LAWS OF MARXISM ON THE DEVELOPMENT OF HUMAN SOCIETY.}

Marx's greatest contribution to social science is to reveal the objective laws of social development, which laid the theoretical foundation of social development. Marxism believes that the development of human society has the performance of the productive forces and production relations campaign contradictory process. The ultimate cause of all social change not from the mind of people's thinking and should change the way of production and exchange. The social development patterns of human change are from lower to higher, from the simple to the complex evolution. The development of human society is from primitive society, slavery, feudalism, capitalism, socialism society after society into communism. It is not the people's will as an objective law. Marx proposed different forms of social development title on different occasions and different writings.

Marx believed that people's full and free development, not only is the inevitable requirement of social development, and is the ultimate goal of social development value. As the ultimate goal of social development value is gradually approaching from the whole process of social development. Marx believed that full and free development of human beings is the main features of the future communist society, pointing out that communist society is everyone's full and free development of social forms. Marx and Engels clearly pointed out that replace with its classes and class antagonisms of the old bourgeois society, would be such a consortium, where everyone's free development of all human freedom development conditions in the landmark famous "Communist Manifesto".

\section{THE SCIENTIFIC CONCEPT OF DEVELOPMENT IS OF DEVELOPMENT OBJECTIVES AND SPECIFIC TO MARXISM-RICH THEORY OF SOCIAL.}

The social is the community of existence and life of real people, from the ideal point of view, the purpose of social development is actually for human beings to create a better life. So the development of society that is human development, namely the development of human social life. For this reason, when the Marxist study of social development issues and concerns the attention and comprehensive study of human development as one of the main content. Marxism believes that the development of social and human development is a process of reunification: human development is inseparable from the society, and the development of human society can not be separated. Social development is a process from lower to higher, turn to experience the primitive society, slave society, feudal social system, capitalism and communism. Consistent with social development, human development experienced human dependency and went to the dependency object shape based on history, it will move towards the overall development of 
the human personality and the freedom of the social form communist society. Thus, the Marxism-round takes people's freedom of personality and human development as the ideal state and objectives. So what is the full development of the human personality and the freedom? Marx believed that the human personality is reflected in the freedom of human nature. In the "1844 Manuscripts", Marx pointed out: Human's personality is precisely the characteristics of human freedom and conscious activity, human nature is human real social contact, so people realize their creation in the positive nature of the process, the production of human society Contact, abstract nature of social forces in general, rather than a social nature with a single person opposed, but the essence of every single individual is his own activity, his own life, his own enjoyment, his wealth.

\section{THE SCIENTIFIC CONCEPT OF DEVELOPMENT ENRICHES THE THEORY OF SOCIAL DEVELOPMENT MECHANISM AND CONCRETE OF MARXISM.}

Marxist theory of social development, not only included the direction of social development, the general law and social development, but also raised the idea of social development mechanism. Marx explored the cause of social development, and stands height dialectical view of the universe, attaches great importance to the internal contradictions of the social role of social development he believed that mutual constraints of various factors within society is a mechanism of social development. As early as 1843, Marx criticized of Hegel's idealism when on the study of the relationship between economics and politics, proposed that civil society made the decision an important political state and the law point of view.

The scientific Concept of Development developed the Marxist theory of social development. It is the scientific concept of development times and Chinese Marxist concept of development. It contains important though that the development of social development of the Marxist theory.

From the historical conditions of the scientific concept of development, this theory is to guide the country's economic and social development of the pointer, with a strong reality. Emphasized the "development" of the scientific concept of development, is based on China's specific national conditions. At present, compared with the early years of reform, there is a new situation on China's economy and society: First, there is a contradiction between the rapid growth of the economy with the development of the imbalance, and resource and environmental constraints; secondly, as people matter, a significant improvement in the spiritual life, there is a contradiction between higher level of living standards, more comprehensive public service-level requirements and incomplete development of public services, the contradiction the level of service is not in place; again, with the people's cultural level and quality of general improvement requires broad participation in society life, they are more concerned with economic reform, adjustment of economic policies will promote economic and social development in the extent to bring tangible benefits to themselves. Above that, we must adhere to the "development" in order to solve new conflicts and new problems arising in the course of reform. Base on this reality, the scientific development concept emphasizes the times, and face open world, combined with China's actual development. From point of views of the socialist core value system, it is to promote and development of Marxist theory of social development embodied values. Lofty ideals of Marxism established is to realize communism and its values is to achieve human liberation and overall development, at the same time, as it to all previous fundamental difference between the old social systems. Therefore we can say, the Marxist theory of social development is about "human development" theory. Scientific concept of development made it clear that the thinking of "people-oriented", this "man" is a specific, realistic person. It is also reflects our party when dealing with the main object relations, made two dialectical unity up to people's needs the interests of people first. Moreover, it is important that meaning scientific concept of development lies from a practical point of view to implement the "people-oriented", which requires the economic and social development of our country must take human needs, comprehensive human development, harmony between man and nature as a development the purpose and destination. To develop all the party line, principles and policies must be based on the fundamental interests of the people. This makes Marxist values into practice has important practical significance, and reflects the development of the Marxist theory on social inheritance, development and innovation. Therefore, "people-oriented" is a concrete manifestation of materialism on a comprehensive theory of human development, also is our party serving the people whole heart and "Power for the People," a new stage of development thinking. It is reflected in the new era, it profoundly reveals the essence of socialism, Marxism is a people-centered values in sharp outlines the nature of socialism and further understanding of the level, and promote the human spirit the three generations of collective leadership of the Party in the new era of.

People first. Core of the scientific development concept is "people-oriented", which artificially fundamental starting point to examine the development of socialism in China, highlights the history of the main theory of historical materialism, especially theories about the history of the subject status. Scientific concept of development emphasizes that maintaining close ties with the masses is our party always invincible, continue to grow and develop the fundamental guarantee. $\mathrm{Hu}$ Jintao solemnly pointed out: "Popular support is to decide a political party, a fundamental factor in the rise and fall of the regime in the theoretical line, principles and policies of the Marxist party and all of the work, by asking public opinion, seeking hearts of the people, can get the support of the masses and support in order to remain invincible. " The biggest political advantage our party is in close contact with the masses and the biggest danger is the ruling party from the masses. Faced with complex and volatile international environment, whether it is to improve the socialist market economic system, or building a moderately prosperous society. It is more need to adhere to the nature and purpose of the Marxist party, and always maintain the party's advanced nature and purity, and always without departing from the masses . The scientific concept of 
development attaches great importance to the masses to play a great role in the development of socialism. Hu stressed that when it comes to the development of socialism, "people of all nationalities are building socialism with Chinese characteristics of the subject, the people's initiative and creativity ensures the success of our cause, realizing the fundamental interests of the overwhelming majority of the people in our party.

\section{THE SCIENTIFIC CONCEPT OF DEVELOPMENT OF COORDINATED DEVELOPMENT CONCEPT}

The more contribution to the Marxist theory of social development scientific concept of development ,not only made it clear that the concept of coordination, coordination specified position in the scientific concept of development, but also the formation of a socialist country on dialectical coordination system construction and reform. In the history of social development of Marxist theory, although in different periods of development has the thinking of coordinated development, this idea has never been stand out like the scientific concept of development, and with a comprehensive and sustainable development tied into implementing one of the three key aspects of the scientific concept of development. It is actually coordination that is in the "comprehensive, coordinated and sustainable" scientific concept of development to the core. Coordinating not only has an independent significance in social development, and its role in the overall development of coherent and sustainable development requirements, from the constraints of their role. In this sense, we can even say that the scientific concept of development is actually coordinated development concept. In terms of China's main problem on social development of is the development of one-sidedness, such as the current five contradictions "five balances" object. The solution to the basic form of this one-sidedness is coordination.

\section{CONCLUSIONS}

The whole of Marxist theory of social development, deeply understand and grasp the basic contradictions of the movement of human society and its laws, it is promote human society and healthy development in line with the law. Scientific Development of "Four in One" and "five lances" requirement, is correctly reflect the social movement of the basic contradictions of socialism, also is solve the fundamental strategy of the basic contradictions in socialist society. Although there is adaptation of production and productivity, and the economic basis of China's socialist, but the existence of certain incompatible or links. Through reform, although some prominent solve the problems, but there are still many conflicts must be resolved. Moreover, the old contradictions are resolved, new conflicts will emerge. New situations emerging economic and social development, social justice issues, such as the spread of corruption, moral decline issues, waste of resources and ecological destruction issues, and unexpected events groups derived there from, etc., makes the degree of contradiction of socialism increasing marginalization and nature. Scientific concept of development that "four in one" socialist development pattern and economic and social development of the "five balances," the guidelines for the "boost productivity and production relations, the economic base and superstructure coordination, promote economic, political, cultural all aspects of the construction of the various aspects of coordination ", [11] is bound to have a positive and profound impact. So the scientific concept of development is not only the experience of China's scientific summary, but a major contribution to the overall development of the Marxist theory of society.

\section{References}

[1] Wang Xiao < The scientific development concept of inheritance and innovation of the Marxist theory of social development> [J] Science and Education Guide (in Xunkan), 2010,08: $167+171$.

[2] Fu Dongsheng <The awareness of Chinese leaders on the development of the Marxist theory of social power $>[\mathrm{J}]$ reform and opening up, 2010,24: 23.

[3] Xiao Xiao <Significant contribution on the scientific concept of development of Marxist theory of social development $>[\mathrm{J}]$ theoretical magazine, 2007,02: 38-40.

[4] Party Kit <Scientific development of the inheritance and development of Marxist theory of social development> [D] Guangxi Normal University, 2010.

[5] Wang Yuxing < The scientific development new contributions to Marxist theory of social development> [D].Zhengzhou University, 2011.

[6] Zhao Xiaolei <The scientific concept of development of Marxist theory of social development, uphold and development> [J] Journal of Shanxi Provincial Committee Party School, 2008,02: 26-28.

[7] ] Guo Yunxing <The scientific concept of development of Marxist theory of social development and rich inheritance> [J] Anyang Normal University, Jan. 2009: 23-26. 